\title{
The Use of Littoral Benthic Macroinvertebrates of the Martín Garcia Island Nature Reserve as Indicators of Water Quality
}

\author{
I. I. César ${ }^{1 *}$, S. M. Martín ${ }^{2}$ and M. F. Colla ${ }^{3}$ \\ ${ }^{1}$ Departament of Biology, Faculty of Exact and Natural Sciences, National University of Mar del Plata \\ and Marine and Coastal Research Institute, Dean Funes 3350, Argentina. \\ ${ }^{2}$ Zoology Invertebrates Division, Natural Sciences Faculty and Museum, La Plata National University, \\ Paseo del Bosque W/N ${ }^{\circ}, 1900$ La Plata, Argentina. \\ ${ }^{3}$ Center for Research and Transference of Catamarca (CITCA-UNCa-CONICET), Prado St. 366, 4700 \\ Catamarca, Argentina.
}

Authors' contributions

This work was carried out in collaboration among all authors. Author IIC designed the study, performed the statistical analysis, wrote the protocol and wrote the first draft of the manuscript. Authors SMM and MFC managed the analyses of the study. Author MFC managed the literature searches. All authors read and approved the final manuscript.

Article Information

DOI: 10.9734/ARRB/2019/v32i130077 Editor(s):

(1) Dr. Paola Angelini, Department of Applied Biology, University of Perugia, Perugia, Italy. (2) Dr. George Perry, Dean and Professor of Biology, University of Texas at San Antonio, USA. Reviewers:

(1) Hiren B. Soni, Institute of Science \& Technology for Advanced Studies \& Research (ISTAR), India. (2) Erika Mayumi Shimabukuro, Universidade de São Paulo, Brazil. Complete Peer review History: http://www.sdiarticle3.com/review-history/49550

Original Research Article

Received 05 April 2019

Accepted 22 June 2019

Published 28 June 2019

\begin{abstract}
At Martín García Island-a Natural Reserve located at the confluence of the Paraná and Uruguay rivers - we used benthic-macroinvertebrate biotic indices to elucidate the structure and community parameters of the littoral benthos and their response to environmental variables and to evaluate the island's coastal water quality. Seasonal campaigns were carried out (March/1995-March/1996) at eight sites of the island's littoral sites, selected according to the substrate characteristics (fine sands, sandy-silty, reedbed, and silty with great hydrophyte development). From the sites with a soft substrate, triplicate samples were extracted using a $225-\mathrm{cm}^{2}$ Ekman manual dredge. The relative abundances of 71 taxa were measured: Nematoda, Turbelaria, Oligochaeta (23 sps.), Mollusca (21
\end{abstract}


sps.), Crustacea (11 sps.), Insecta (12 families), and Tardigrada. Macroinvertebrate density: 1558,800 ind $\mathrm{m}^{-2}$. Analysis of variance revealed significant differences between the average annual macroinvertebrate-population densities among the five sites ( $F: 3.059 ; p<0.05$ ). Site 7 exhibited the highest density at $38,700 \pm 19,000$ ind $\mathrm{m}^{-2}$ Community parameters: diversity (H'; 0.77-2.16 bits); equitability ( $\mathrm{J} ; 0.16-1.02)$, and species richness (S; 3-29). Canonical-correspondence analysis indicated the environmental variables experiencing the greatest fluctuation to be: dissolved-oxygen concentration, $\mathrm{pH}$, temperature, and conductivity. The results of this analysis suggest that macroinvertebrate-species distribution involves the physicochemical conditions of the water. Of the correlation between species and environmental variables, $95.5 \%$ were distributed on the canonicalcorrespondence ordering diagram's Axis 1. Functional feeding groups: In all sites and seasons, the gathering collectors predominated, followed by the scrapers, filtering collectors, shredders, and predators. Macroinvertebrate Index of Pampean-Rivers: values generally ranged from weak to weak-to-very-weak to zero pollution, but there was a high degree of pollution (2.4 and 1.5) in the spring of 1995.

Keywords: Benthos; macroinvertebrates; water quality; Martín García Island.

\section{INTRODUCTION}

The freshwater bio-evaluation is based on the natural capacity of the biota to respond to the effects of eventual or permanent disturbances. By modifying the environmental conditions of natural habitats, the aquatic biota changes its structure and functioning.

According to the statement, it is possible to use some characteristics or structural and functional properties of the different levels of biological organization to evaluate in a comparative way the state of the aquatic biota, whose condition is a reflection of the ecological state of the water body. These evaluation characteristics are known by the generic name of bioindicators.

In general, the condition of the entire biotic community is not evaluated but that of some groups of organisms such as plankton, fish and invertebrates, these have been the groups most used in bioindication studies [1].

The benthic macroinvertebrates have been highlighted in these studies, these are the invertebrates that inhabit the bottom of the aquatic ecosystems, either permanently or at some stages of their life cycle and that are retained in networks with an equal pore opening or less than $500 \mathrm{m \mu}$ [2].

The benthic fauna includes diverse groups of invertebrates (molluscs, oligochaetes, hirudineans, flatworms, crustaceans, mites and the juvenile stages of several insects).

The predilection for benthic macroinvertebrates is due to several reasons indicated by Reece and
Richardson [3]: their relative sedentarism and representativeness in the collection area; relatively short life cycles that more quickly reflect changes in the environment through changes in structure of its populations and communities; they live and feed in or on the sediments in which the toxins tend to accumulate, which are incorporated into the trophic chain through them; its sensitivity to the factors of disturbance and response to contaminating substances present in both water and sediments; they are primary source of many fish, and participate in an important way in the degradation of organic matter and the nutrient cycle.

Currently, the use of benthic macroinvertebrates is an excellent methodological alternative to detect the early modifications and/or of diffuse origin that occur in aquatic ecosystems [4,5,6, $7,8,9]$.

In Argentina, benthic macroinvertebrates have been used with reference to the structure of the rivers community, its seasonal variations $[10,11$, $12,13,14]$ and as a water quality indicators for different regions of the country. The indices for the rivers of Córdoba and San Luis provinces $[15,16]$; for the Litoral region [17]; for the Buenos Aires province $[18,19]$; for the Patagonia $[20,21$, 22]; and for the Argentine northwest rivers [23, 24,25,26]. The Martín García Island Multiple-use Reserve is located at the confluence of the Paraná and Uruguay rivers (the uppermost portion of the Río de la Plata) at $34^{\circ} 11^{\prime} \mathrm{S}$ and $58^{\circ} 15^{\prime} \mathrm{W}$. The $1990 \mathrm{~s}$ marked the beginning of studies on the biota of the Island that was particularly characterized by the contributions of 
[27] on tree and shrub trees; followed by investigations on vertebrates [28,29,30], aquatic invertebrates [31] molluscs, telencephalic flatworms [32], and aquatic and semiaquatic insects [33] among others. Since 2000, studies on the invertebrate fauna have been intensified, both along the island's coast and in the interior ponds $[34,35,36,37,38,39,40,41,42,43,44,45,46$, $47,48]$.

The aim of this work was to gather further information about the structure of the littoral benthos with respect to the community parameters along with their response to environmental variables and also to evaluate the water quality along the island's coast by using biotic indices based on the benthic macroinvertebrates.

\section{MATERIALS AND METHODS}

\subsection{Description of the Environment}

The Río de la Plata estuary-220 kilometres long, 35 to 230 kilometres wide, and a temperate micro-tidal system-contains a freshwater environment in the upper region where the Paraná and Uruguay rivers converge, with an average discharge of $20,000-25,000 \mathrm{~m}^{3} . \mathrm{s}^{-1}$. The river's coasts border on both Uruguay and Argentina. This system is one of the major estuaries in South America and the first in terms of economic relevance and the magnitude of the human populations linked to its coasts [49].

This island (see Fig.1) consists of an outcropping of the crystalline basement, unevenly overlaid by Pleistocene and HOLOCENE sediments [50,51, 52]. Ever since the island's declaration as a natural reserve in 1969, Martín García has been under the administration of the provincial agency for sustainable development of the province of Buenos Aires.

The littoral zones of the island exhibit a marked asymmetry, with the western and northern coasts receiving clayey silt sediments, which particles over time become initially deposited on the otherwise rocky substrate and then consolidated by marsh-vegetation growth. In contrast, along the eastern and southern coasts, the rocky substrate has little silty sediment and instead is covered mainly by fine sands, with that deposit resulting in part from the action of strong winds from the southeast. This coastal functional asymmetry favours the differential distribution of vegetation. Thus, on the northern coasts (see site 7, Fig. 1) extensive grasslands and reedbeds have developed, containing approximately 16 hydrophyte species. The benthos farther along the west coast (see site 8, Fig. 1) is characterized by mixed sediments of sand and silt and lies in the vicinity of a dump, constituting a source of anthropic impact. To the south of the island is site 1, a sandy beach with the development of reedbeds of Schoenoplectus californicus. Site 2 is situated in the southeastern end along with site 3 (the water-intake area of the island). The substrate there is mainly rocky, whereas a little farther north, a small beach of clean sand (site 4) has developed along with pools at site 5 farther up the coast. To the north, extensive reedbeds of $S$. californicus are present at site 6 .

\subsection{The Sampling}

The sampling was conducted on five occasions from summer, autumn, winter, spring 1995 to summer 1996, at the eight sites along the island's coast (see Fig. 1), selected according to the characteristics of the substrate (fine sands, sandy-silty, reedbed, and silty with great development of hydrophytes). In sites with soft substrate (sand or silt), triplicate samples per site were extracted using an ekman manual dredge $(225 \mathrm{~cm} 2)$ and then fixed with 10\% (v/v) aqueous formaldehyde. In sites 3 and 5 , the specimens were collected with $15-\mathrm{cm}$ diameter and $0.14-$ $\mathrm{mm}$-mesh-size sieves (captures per unit effort = specimens $/ 30 \mathrm{~min} /$ person) to obtain the relative abundance of individuals per hour [53].

The following physicochemical variables were measured with portable digital sensors: water temperature $\left({ }^{\circ} \mathrm{C}\right)$, dissolved-oxygen concentration $\left(\mathrm{mg} . \mathrm{I}^{-1}\right)$, electrical conductivity $\left(\mu \mathrm{s} . \mathrm{cm}^{-1}\right)$, and $\mathrm{pH}$.

\subsection{Treatment of the Samples}

In the laboratory, the samples were washed on a $125-\mu \mathrm{m}$ mesh screen, or flotation techniques were applied [54] according to the type of substrate. The material was then stained with Erythrosin b. The specimens were characterized qualitatively and quantitatively by microscopy and conventional scoring techniques. The taxonomical determinations were made through the use of the specialized literature pertaining to the particular groups $[55,56,57,58]$.

\subsection{Data Analyses}

The species diversity $\left(\mathrm{H}^{\prime}\right)$ was calculated according to the Shannon-Wiener index, the 
species richness $S$ [59], and the equitability $(\mathrm{J})=$ $H^{\prime} /$ In S [60]. Graphs were constructed with the Excel to determine the relative abundance per sampling site and season of the year. The taxa included corresponded to those that exceeded a $1 \%$ representation for the purpose of greater graphical clarity.

To ascertain the variation in the average annual density of the macroinvertebrates among the sampling sites, an Analysis of Variance (ANOVA) supplemented with a Bonferroni post-hoc test was performed $(p<0.05)$ by means of the statistical software SPSS v. 22. Data were previously log-transformed in order to meet the requirements of the analysis. This analysis was not performed on Sites 3 and 5 because the sampling arts were different (catch per unit of effort) and therefore, the results are not comparable.

For an analysis of the trophic structure of the benthos, the functional food groups were characterized in each sampling site and for the two years, according to preexisting classifications-namely, a grouping into shredders, gathering collectors, filtering collectors, scrapers, and predators $[61,62,63$, $64,65,66]$.

Because martín garcía island had been classified as a nature reserve, we examined the water quality along the coast, applying the biotic index macroinvertebrate index of pampean-rivers (MIPR) [67,68,69]; based on the sum of the values of ecologic sensitivity (vx), varying from 0 to infinity with the lowest values corresponding to highly disturbed environments:

$$
\text { MIPR }=\sum_{X=1}^{N}(V X)
$$

Of the 71 taxa found, only those being represented by more than $1 \%$ of the total invertebrates collected were considered [70] along with the 15 most abundant and most frequent species in conjunction with the corresponding 4 most relevant environmental variables.

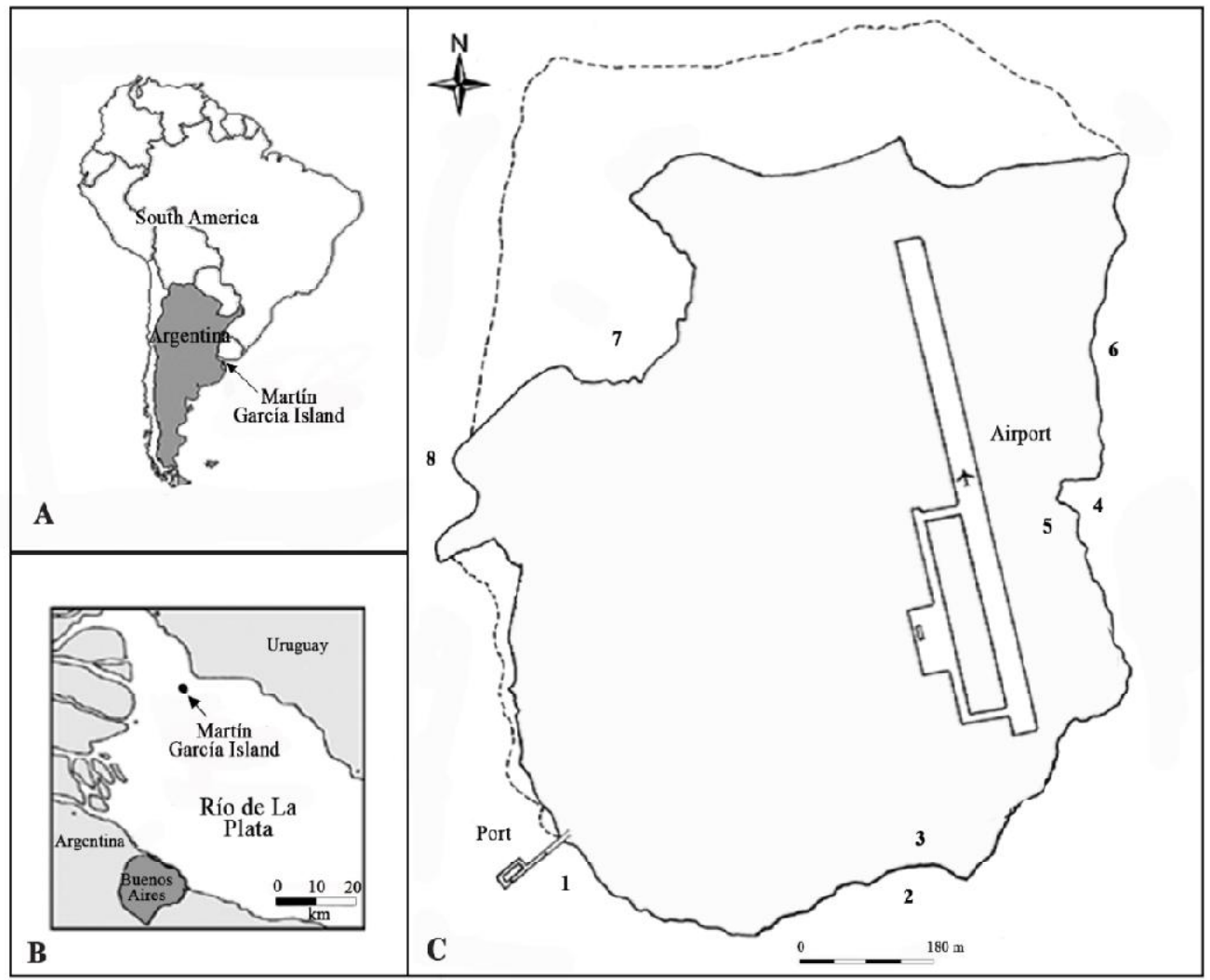

Fig. 1. Location of the natural reserve island of Martín García (Argentina) in a: South America b: The Estuary of Rio de la Plata River. C: Map of the island showing study sites 1-8 
Table 1. Sites, Geographical coordinates and fisico-chemical parameters considered

\begin{tabular}{|c|c|c|c|c|c|}
\hline & Geographical coordinates & ${ }^{\circ} \mathrm{C} \mathrm{T}$ & DO & Conductivity & $\mathrm{pH}$ \\
\hline Site 1 & $\begin{array}{l}34^{\circ} 11^{\prime} 24^{\prime \prime} \mathbf{S} \\
58^{\circ} 15^{\prime} 20^{\prime \prime} \mathbf{W}\end{array}$ & 26.65 & 5.96 & 112.95 & 9.05 \\
\hline Site 2 & $\begin{array}{l}34^{\circ} 11^{\prime} 25^{\prime \prime} \mathbf{S} \\
58^{\circ} 14^{\prime} 56^{\prime \prime} \mathrm{W}\end{array}$ & 20.33 & 6.01 & 127.17 & 6.83 \\
\hline Site 3 & $\begin{array}{l}34^{\circ} 11^{\prime} 23^{\prime \prime} \mathrm{S} \\
58^{\circ} 14^{\prime} 58^{\prime \prime} \mathrm{W}\end{array}$ & 26.52 & 5.53 & 113 & 5.9 \\
\hline Site 4 & $\begin{array}{l}34^{\circ} 10^{\prime} 54^{\prime \prime} \mathrm{S} \\
58^{\circ} 14^{\prime} 36^{\prime \prime} \mathrm{W}\end{array}$ & 23.25 & 7.53 & 171.65 & 7.91 \\
\hline Site 5 & $\begin{array}{l}34^{\circ} 10^{\prime} 63^{\prime \prime} \mathrm{S} \\
58^{\circ} 14^{\prime} 39^{\prime \prime} \mathrm{W}\end{array}$ & 21.33 & 1.06 & 176.7 & 5.72 \\
\hline Site 6 & $\begin{array}{l}34^{\circ} 10^{\prime} 22^{\prime \prime} \mathrm{S} \\
58^{\circ} 14^{\prime} 35^{\prime \prime} \mathrm{W}\end{array}$ & 20.76 & 8.6 & 117.22 & 7.54 \\
\hline Site 7 & $\begin{array}{l}34^{\circ} 10^{\prime} 42^{\prime \prime} \mathrm{S} \\
58^{\circ} 15^{\prime} 61^{\prime \prime} \mathrm{W}\end{array}$ & 20.1 & 8.47 & 160.24 & 6.58 \\
\hline Site 8 & $\begin{array}{l}34^{\circ} 10^{\prime} 83^{\prime \prime} \mathbf{S} \\
58^{\circ} 15^{\prime} 35^{\prime \prime} \mathbf{W}\end{array}$ & 31 & 11 & 99.8 & 9.24 \\
\hline
\end{tabular}

Relationships between species and environmental variables were examined with canonical correspondence analysis (cca), considering the fifteen most abundant and most frequently occurring species and four environmental variables, the temperature of the air and the tds contained redundant information (inflation factors > 20), Therefore they were not considered in the analysis [71,72,73,74]. The mean value of each environmental variable together with data on abundance species from eight sampling stations were used in cca. the statistical package used was mvsp 3.1.

The associations between species and sites were examined by the grouping-analysis technique Unweighted Pair Group Method with Arithmetic Mean (UPGMA), through the application of the Jaccard index (75), with the species considered being the same as those used for the CCA.

\section{RESULTS}

\subsection{Relative Abundance}

For estimating the relative abundance of the benthic macroinvertebrates present, a total of 71 taxa were collected (as shown in Table 1 and Fig. 2). At site 1 (see Fig. 2, a), in the autumn 1995, the only taxa recorded were the gastropods and bivalves; with the highest abundances represented by Heleobia piscium (d'orbigny), Biomphalaria straminea (dunker)
Hebetancylus moricandi (d'orbigny), Uncancylus concentricus (d'orbigny), and Corbicula fluminea (müller).

During winter 1995, the nematoda predominated with lower relative abundances of turbelaria and oligochaeta, the last of these represented by the family enchytraeidae plus a further 4 species among which Limnodrilus hoffmeisteri Claparède of the Tubificidae was the most abundant. The bivalves were represented by $C$. fluminea; and Sinelobus stanfordi (Richardson) was the most abundant crustacean, along with certain members of the phylum Tardigrada in addition to larvae of the Diptera Chironomidae. In spring of 1995, in addition to the benthos sampling, the reeds were surveyed by means of the captureper-unit-of-effort technique. Of the benthic macroinvertebrates, the highest relative abundance corresponded to the crustaceans, the copepods, and the ostracod Darwinula stevensoni (Brady \& Robertson) followed by the Chironomidae and Narapa bonettoi Righi and Varela (Oligochaeta). The nematoda and the ostracods exhibited essentially the same abundance, while the harpacticoid and calanoid copepods likewise manifested similar abundances. The results of the capture per unit of effort demonstrated a clear predominance of gastropods such as Potamolithus buschii (Fraunfeld), U. concentricus, and H. piscium. For summer 1996, the highest relative abundances corresponded to the nematoda, the bivalve $C$. fluminea, and the Chironomidae. 
At site 2 (as shown in Fig. 2, B), In summer 1995, the gastropods Potamolithus agapetus Pilsbry, Potamolithus lapidum (d'orbigny), and Chironomidae contributed the highest relative Abundance. During The Autumn, The Bivalves Limnoperna fortunei (Dunke) and C. fluminea became prominent in addition to the gastropods B. straminea and Chilina megastoma Hylton
Scott. In the spring of that year, the gastropods $P$. agapetus and $P$. buschii manifested the highest relative abundances followed by the isopod Pseudosphaeroma platense (GIAMBIAGI). Summer 1996 was characterized by the presence of gastropods at the greatest relative abundance, particularly $P$. buschii, $P$. agapetus, and $H$. moricandi.
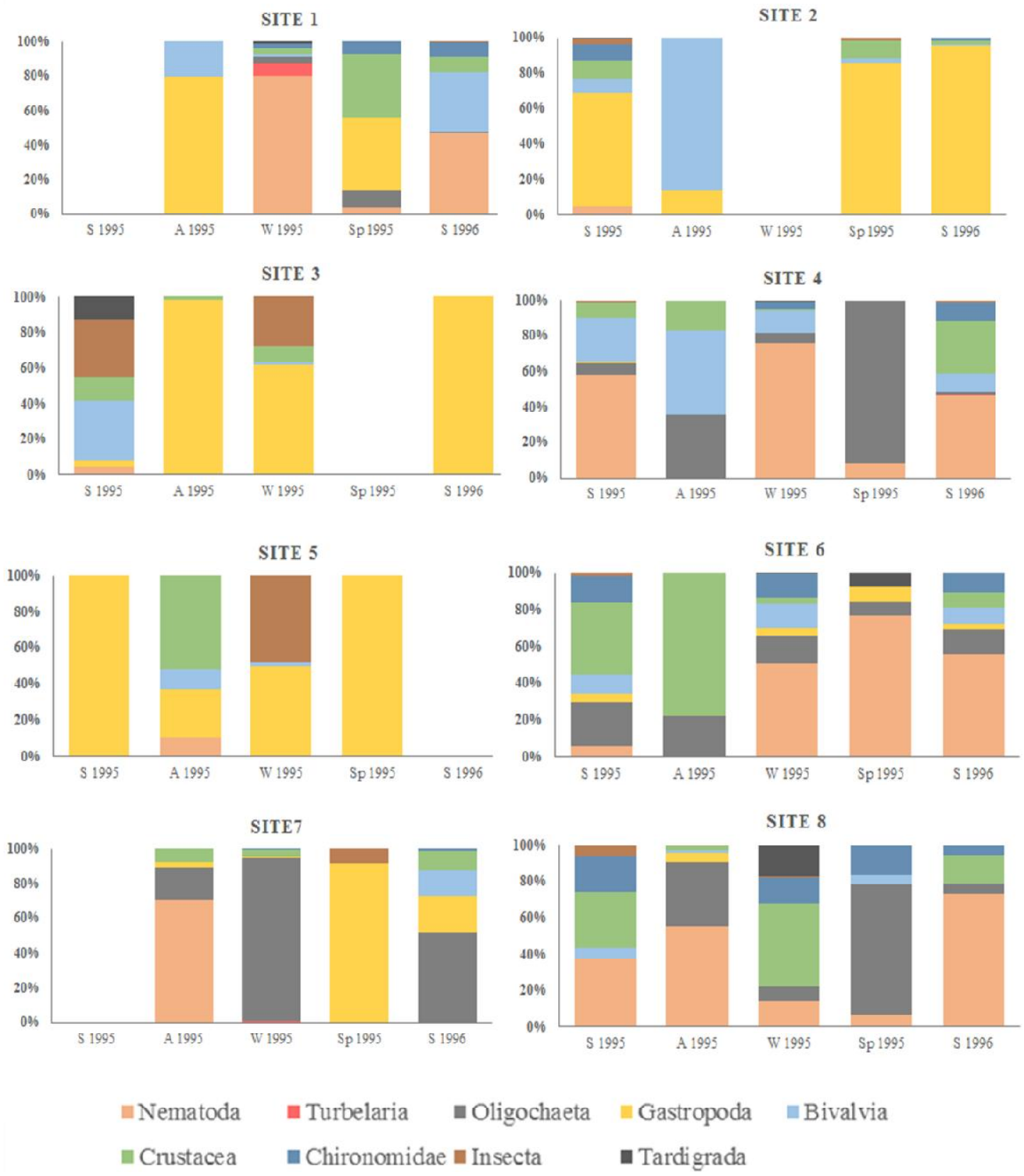

Fig. 2. Relative abundance of macroinvertebrates in Isla Martín García natural reserve 
Table 2. List of the benthic taxa (presence-absence) and functional feeding groups in the Isla Martín García Natural Reserve during the studied period

\begin{tabular}{|c|c|c|c|c|c|c|c|c|c|}
\hline \multirow[t]{2}{*}{$\overline{\text { Taxa }}$} & \multicolumn{5}{|c|}{ Sites } & \multicolumn{4}{|c|}{ Functional feeding groups } \\
\hline & 1 & 2 & 3 & 4 & 5 & 6 & 7 & 8 & \\
\hline Nematoda & $x$ & $\mathrm{x}$ & $x$ & $x$ & $x$ & $\mathrm{x}$ & $x$ & $x$ & Gathering collectors \\
\hline Turbelaria & $x$ & & & $x$ & & & $x$ & & Predators \\
\hline Hirudinea & $x$ & & & & & $x$ & $x$ & & Predators \\
\hline \multicolumn{10}{|l|}{ Oligochaeta } \\
\hline Pristina rosea & $x$ & & & $x$ & & $x$ & $x$ & $x$ & Gathering collectors \\
\hline P. breviseta & & & & & & & $x$ & $x$ & Gathering collectors \\
\hline P. osborni & & & & $x$ & & $x$ & $x$ & $x$ & Gathering collectors \\
\hline P. longiseta & & & & $x$ & & & $x$ & $x$ & Gathering collectors \\
\hline$P$. aequiseta & & & & & & $x$ & $x$ & & Gathering collectors \\
\hline P. acuminata & & & & $x$ & & & $x$ & & Gathering collectors \\
\hline Amphichaeta leydigi & $x$ & & & $x$ & & $x$ & $x$ & $x$ & Gathering collectors \\
\hline Eiseniella tetraedra & & & & & & $x$ & $x$ & $x$ & Gathering collectors \\
\hline Nais variabilis & $x$ & & & & & $x$ & $x$ & $x$ & Gathering collectors \\
\hline Slavina evlinae & $x$ & & & & & & $x$ & & Gathering collectors \\
\hline Stephensoniana trivandrana & $x$ & & & & & $x$ & $x$ & $x$ & Gathering collectors \\
\hline Aulophorus furcatus & & & & & & & $x$ & & Gathering collectors \\
\hline Dero obtusa & & & & & & & $x$ & & Gathering collectors \\
\hline D. sawayai & & & & & & & $x$ & & Gathering collectors \\
\hline Chaetogaster diastrophus & & & & $x$ & & $x$ & $x$ & $x$ & Predators \\
\hline C. diaphanus & & & & & & & $x$ & $x$ & Predators \\
\hline Stylaria lacustris & & & & & & & $x$ & $x$ & Gathering collectors \\
\hline Narapa bonettoi & $x$ & & & $x$ & & $x$ & & & Gathering collectors \\
\hline Limnodrilus hoffmeisteri & $x$ & & & $x$ & & $x$ & $x$ & $x$ & Gathering collectors \\
\hline L. udekemianus & $x$ & & & & & & $x$ & $x$ & Gathering collectors \\
\hline Aulodrilus pigueti & $x$ & & & & & $x$ & $x$ & $x$ & Gathering collectors \\
\hline Aelosomatidae & $x$ & & & $x$ & & $x$ & $\mathrm{x}$ & $x$ & Gathering collectors \\
\hline \multicolumn{10}{|l|}{ Mollusca } \\
\hline Pisidium sterkianum & & $x$ & & & $x$ & & $x$ & & Filtering collectors \\
\hline P. taraguyense & & & $x$ & & & & & & Filtering collectors \\
\hline Limnoperna fortunei & & $x$ & & & $x$ & $x$ & $x$ & & Filtering collectors \\
\hline Corbicula fluminea & $x$ & $x$ & $x$ & $x$ & $x$ & $x$ & $x$ & $x$ & Gathering collectors \\
\hline Heleobia parchapii & $x$ & $x$ & $x$ & & $x$ & $x$ & $x$ & $x$ & Scrapers \\
\hline H. piscium & $x$ & & & & $x$ & $x$ & $x$ & & Scrapers \\
\hline Uncancylus concentricus & $x$ & & $x$ & $x$ & & $x$ & $x$ & & Scrapers \\
\hline Hebetancylus moricandi & $x$ & $x$ & $x$ & $x$ & $x$ & $x$ & $x$ & & Scrapers \\
\hline Potamolithus bushii & $x$ & $x$ & $x$ & $x$ & $x$ & $x$ & & & Scrapers \\
\hline P. lapidum & & $x$ & $x$ & & $x$ & & & & Scrapers \\
\hline$P$. agapetus & & $x$ & $x$ & & $x$ & & & & Scrapers \\
\hline Pomacea canaliculata & & $x$ & $x$ & & $x$ & & $x$ & $x$ & Scrapers \\
\hline P. megastoma & & & & & & & & $x$ & Scrapers \\
\hline Asolene platae & $x$ & $x$ & $x$ & & $x$ & $x$ & $x$ & $x$ & Scrapers \\
\hline Biomphalaria straminea & & & $x$ & & $x$ & & $x$ & & Scrapers \\
\hline Drepanotrema kermatoides & & & & & $x$ & & $x$ & & Scrapers \\
\hline D. depressisimun & & & & & $x$ & & & & Scrapers \\
\hline Chilina fluminea & & $x$ & & & $x$ & $x$ & & & Scrapers \\
\hline Ch. megastoma & & & $x$ & & & & & & Scrapers \\
\hline Ch. rushi & & & $x$ & & & & & & Scrapers \\
\hline Stenophysa marmorata & & & $x$ & & & & & & Scrapers \\
\hline Tardigrada & $x$ & $x$ & & & & $x$ & $\mathrm{x}$ & $x$ & Scrapers \\
\hline
\end{tabular}




\begin{tabular}{|c|c|c|c|c|c|c|c|c|c|}
\hline \multirow[t]{2}{*}{ Taxa } & \multicolumn{5}{|c|}{ Sites } & \multicolumn{4}{|c|}{ Functional feeding groups } \\
\hline & $\overline{1}$ & 2 & 3 & 4 & 5 & 6 & 7 & 8 & \\
\hline \multicolumn{10}{|l|}{ Crustacea } \\
\hline Cytheridella argentinensis & & $\mathrm{x}$ & & $x$ & & $\mathrm{x}$ & $\mathrm{x}$ & $\mathrm{x}$ & Shredders \\
\hline Limnocytere paranensis & $\mathrm{x}$ & $\mathrm{x}$ & & $\mathrm{x}$ & $\mathrm{x}$ & & & $\mathrm{x}$ & Shredders \\
\hline Darwinula stevensoni & $\mathrm{x}$ & & & $\mathrm{x}$ & & $\mathrm{x}$ & $\mathrm{x}$ & $\mathrm{x}$ & Shredders \\
\hline lliocypris gibba & $x$ & & & $x$ & & $x$ & $x$ & $x$ & Shredders \\
\hline Cypridopsis vidua & & & & & & $\mathrm{x}$ & & & Shredders \\
\hline Pseudophaeroma platense & $\mathrm{x}$ & $\mathrm{x}$ & $\mathrm{x}$ & $\mathrm{x}$ & $\mathrm{x}$ & $\mathrm{x}$ & & $\mathrm{x}$ & Predators \\
\hline Claudicuma platensis & $\mathrm{x}$ & $\mathrm{x}$ & & $\mathrm{x}$ & & & & & Gathering collectors \\
\hline Sinelobus stanfordi & $\mathrm{x}$ & & & $\mathrm{x}$ & & $\mathrm{x}$ & $\mathrm{x}$ & $\mathrm{x}$ & Gathering collectors \\
\hline Hyalella curvispina & & $\mathrm{x}$ & $\mathrm{x}$ & & & $\mathrm{x}$ & $\mathrm{x}$ & $\mathrm{x}$ & Gathering collectors \\
\hline Aegla uruguayana & & & & $\mathrm{x}$ & & $\mathrm{x}$ & & & Gathering collectors \\
\hline A. platensis & & $\mathrm{x}$ & & $\mathrm{x}$ & & & & & Gathering collectors \\
\hline \multicolumn{10}{|l|}{ Insecta } \\
\hline Diptera :Chironomidae & $x$ & $\mathrm{x}$ & & $\mathrm{x}$ & $\mathrm{x}$ & $x$ & $\mathrm{x}$ & $x$ & Gathering collectors \\
\hline Diptera Ceratopogonidae & $\mathrm{x}$ & $\mathrm{x}$ & & & & $\mathrm{x}$ & $\mathrm{x}$ & $\mathrm{x}$ & Predators \\
\hline Diptera Culicidae & & $\mathrm{x}$ & $\mathrm{x}$ & & & & & $\mathrm{x}$ & Gathering collectors \\
\hline Coleoptera Psephaenidae & & $\mathrm{x}$ & $\mathrm{x}$ & $\mathrm{x}$ & $\mathrm{x}$ & $\mathrm{x}$ & & & Shredders \\
\hline Coleoptera Elmidae & & $\mathrm{x}$ & $\mathrm{x}$ & & & & & $\mathrm{x}$ & Gathering collectors \\
\hline Ephemeroptera Baetidae & & $\mathrm{x}$ & $\mathrm{x}$ & & $\mathrm{x}$ & $\mathrm{x}$ & & $x$ & Gathering collectors \\
\hline Ephemeroptera Leptophlebiidae & & $\mathrm{x}$ & & & & $\mathrm{x}$ & & & Predators \\
\hline Hemiptera Pleidae & & $\mathrm{x}$ & & & & & $\mathrm{x}$ & $\mathrm{x}$ & Predators \\
\hline Odonata Coenagrionidae & & & $\mathrm{x}$ & & $\mathrm{x}$ & & & $x$ & Predators \\
\hline Odonata Protoneuridae & & & $\mathrm{x}$ & & $\mathrm{x}$ & & & & Predators \\
\hline Odonata Libelullidae & & & & & & & $\mathrm{x}$ & & Predators \\
\hline Trichoptera Hydroptilidae & & & $\mathrm{x}$ & & & & $\mathrm{x}$ & & Gathering collectors \\
\hline
\end{tabular}

At Site 3 (see Fig. 2, C) in summer 1995, C. fluminea was the species of greatest relative abundance, followed by $P$. platense and the insects represented by the Coleoptera.

Psephenidae and Elmidae. In the fall, 1995 a predominance of gastropods $(96 \%)$ featured Drepanotrema depressissimum (Moricand) as the species of highest abundance followed by Stenophysa marmorata (Guilding) and Pomacea canaliculata (Lamark). In winter 1995, gastropods, and particularly to Heleobia parchapii, manifested the highest relative abundance along with the insects, especially represented by the predominance of the Psephaenidae. The other species of gastropods were $B$. straminea and Chilina rushi Pilsbry along with the amphipods Hyallela curvispina Shoemaker and $S$. marmorata at similar densities. In the spring, no taxa were found. In summer 1996, only the gastropods $P$. agapetus, $H$. moricandi, and B. straminea were recorded, and of these three the first exhibited the greatest relative abundance.

At Site 4 (as shown in Fig. 2, D), in summer 1995, the highest abundances corresponded to the Nematoda, C. fluminea and immature oligochaetes of the Tubificidae. In autumn, the bivalve $C$. fluminea contributed the greatest relative abundance, followed by $N$. bonettoi and the ostracod Limnocythere paranensis Ferguson. During the winter, the Nematoda again predominated followed by $C$. fluminea, $N$. bonettoi, and the Chironomidae. In the spring, $N$. bonettoi predominated over a background of lower-abundance groups. Whereas, in summer 1996, the macroinvertebrates with high relative abundances were the Nematoda, harpacticoid copepods, and Chironomidae plus the bivalve $C$. fluminea and the ostracod L. paranensis.

At Site 5 (see Fig. 2, E), in summer 1995, only gastropod molluscs were recorded with the highest relative abundance represented by $P$. buschii followed by $H$. moricandi, B. straminea, $P$. canaliculata, and Drepanotrema kermatoides (D'Orbigny). In the autumn, the crustacean copepods of the order Cyclopoida were dominant over the gastropods $H$. piscium and $C$. fluminea. In the winter, the Coleoptera Psephenidae along with the gastropods $P$. buschii and $P$. agapetus exhibited a greater relative abundance, with those latter species being present at comparable relative densities. In the spring, only the gastropods were registered, with $\mathrm{H}$. parchapii and $H$. piscium having the highest abundances. No records were obtained during the summer of 1996. 
At Site 6 (see Fig. 2, F), in summer 1995, the tanaids $S$. stanfordi, the Chironomidae family, and the bivalve $C$. fluminea were the most abundant. In autumn, the greatest abundance was registered with the crustaceans $H$. curvispina and $S$. stanfordi followed by the Enchytraeidae oligochaetes. In winter, the Nematoda predominated followed by the family Chironomidae, C. fluminea, and Amphichaeta leydigi Tauber. The spring was characterized by a clear predominance of the Nematoda; whereas $N$. bonettoi, $H$. piscium, and the species of Tardigrada present exhibited similar, though lesser abundances. For summer 1996, the Nematoda manifested a still greater relative abundance followed by the Chironomidae, the oligochaete Stephensoniana trivandrana (Aiyer), and the bivalve $C$. fluminea.

At Site 7 (as shown in Fig. 2, G), in fall 1995, the greatest relative abundance was registered with the Nematoda. During the winter, the oligochaetes $A$. leydigi and $N$. variabilis predominated. $H$. parchapii was the species that predominated, followed by the insects Pleidae. Whereas, in summer 1996, S. trivandrana reached the highest relative abundance followed by $P$. agapetus, $L$. fortunei, Dero sawayai Marcus, the cyclopoid copepods, and $L$. hoffmeisteri.

At Site 8 (see Fig. 2, H), in summer 1995, the Nematoda were distinguished by their high relative abundance, followed by the Chironomidae, Cyclopoida copepods, the ostracod $D$. stevensoni, and the isopod $P$. platense. In the fall, along with a notable abundance of $S$. stanfordi followed by the harpacticoid copepods and the oligochaetes $L$. hoffmeisteri, species of the Enchytraeidae, and Nais variabilis Piguet; ostracod species such as D. stevensoni, C. argentinensis, and Iliocypris gibba Brady \& Norman contributed to the assemblage at a relative abundance of $10 \%$. In the winter, the harpacticoid copepods exhibited the highest relative abundance followed by the Tardigrada, Nematoda, Chironomidae, Cladocera, and the ostracod $D$. stevensoni. In the spring, the species with the highest relative abundances were $L$. hoffmeisteri, Aulodrilus pigueti Kowalewski, and those of the Chironomidae. Whereas, in summer 1996, the Nematoda manifested the greatest relative abundance followed by the Chironomidae, the calanoid copepods and the cyclopoids.

For Sites 1 and 7 we have no records for the summer-1995 campaign because the sudden rise in the tide prevented any sampling. Furthermore, at Site 2 no organisms were registered during the winter of 1995.

\subsection{Macroinvertebrates Density}

The density of the benthic macroinvertebrates ranged from 15 to 58,800 ind.m-2. The ANOVA revealed significant differences between the values for the average annual population density (log10 density) of macroinvertebrates among the five sites included in the analysis ( $F$ : 3.059; $p$ $<0.05)$. The highest average population density was recorded at Site $8(38,700 \pm 19,000$ ind.m2.) (Fig. 3).

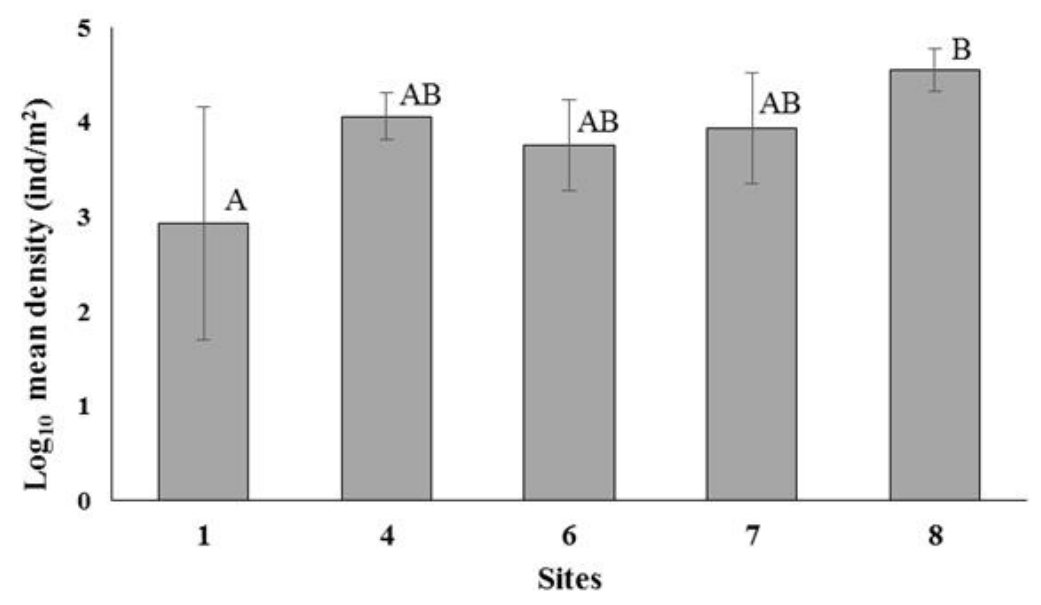

Fig. 3. Mean population density (log 10 density) of benthic invertebrates in five study sites of the natural reserve of Martín García island. Bars represent the mean values and lines indicate standard deviation. Bars with at least one letter in common don't differ statistically $(p>0.05)$ 
Table 3. Community parameters (species richness, S; diversity, $\mathrm{H}^{\prime}$, and evenness, $\mathrm{J}^{\prime}$ ) for the eight aquatic sampling sites on Martín García island, analyzed seasonally (summer 1995 through summer 1996); *s, summer; a, autumn; w, winter; sp, spring

\begin{tabular}{llllllllll}
\hline $\begin{array}{l}\text { Community } \\
\text { parameters }\end{array}$ & Seasons $^{*}$ & \multicolumn{10}{c}{ Sites } \\
\cline { 2 - 10 } & & $\mathbf{1}$ & $\mathbf{2}$ & $\mathbf{3}$ & $\mathbf{4}$ & $\mathbf{5}$ & $\mathbf{6}$ & $\mathbf{7}$ & $\mathbf{8}$ \\
\hline Species richness & $\mathrm{S}-95$ & - & 13 & 11 & 16 & 7 & 25 & - & 17 \\
& $\mathrm{~A}-95$ & 5 & 6 & 9 & 8 & 15 & 12 & 29 & 25 \\
& $\mathrm{~W}-95$ & 20 & - & 13 & 13 & 6 & 26 & 24 & 26 \\
& $\mathrm{Sp}-95$ & 15 & 7 & - & 9 & 7 & 5 & 10 & 9 \\
& $\mathrm{~S}-96$ & 13 & 7 & 3 & 17 & 16 & 13 & 23 & 11 \\
\hline Diversity index & $\mathrm{S}-95$ & - & 1.29 & 2.08 & 1.33 & 1.59 & 2.10 & - & 1.96 \\
& $\mathrm{~A}-95$ & 1.44 & 1.83 & 1.49 & 1.26 & 1.82 & 1.56 & 1.53 & 1.47 \\
& $\mathrm{~W}-95$ & 1.00 & - & 2.2 & 1.09 & 1.27 & 1.62 & 1.35 & 2.16 \\
& $\mathrm{Sp}-95$ & 1.95 & 1.14 & - & 0.35 & 1.29 & 1.13 & 0.92 & 1.76 \\
& $\mathrm{~S}-96$ & 1.38 & 0.77 & 0.77 & 1.6 & 1.76 & 1.57 & 1.95 & 1.12 \\
\hline Evenness index & $\mathrm{S}-95$ & - & 0.50 & 0.87 & 0.48 & 0.82 & 0.65 & - & 0.69 \\
& $\mathrm{~A}-95$ & 0.90 & 1.02 & 0.68 & 0.61 & 0.67 & 0.63 & 0.46 & 0.46 \\
& $\mathrm{~W}-95$ & 0.33 & - & 0.86 & 0.42 & 0.71 & 0.50 & 0.43 & 0.66 \\
& $\mathrm{Sp}-95$ & 0.72 & 0.59 & - & 0.16 & 0.66 & 0.70 & 0.40 & 0.80 \\
& $\mathrm{~S}-96$ & 0.54 & 0.40 & 0.70 & 0.56 & 0.63 & 0.61 & 0.62 & 0.47 \\
\hline
\end{tabular}

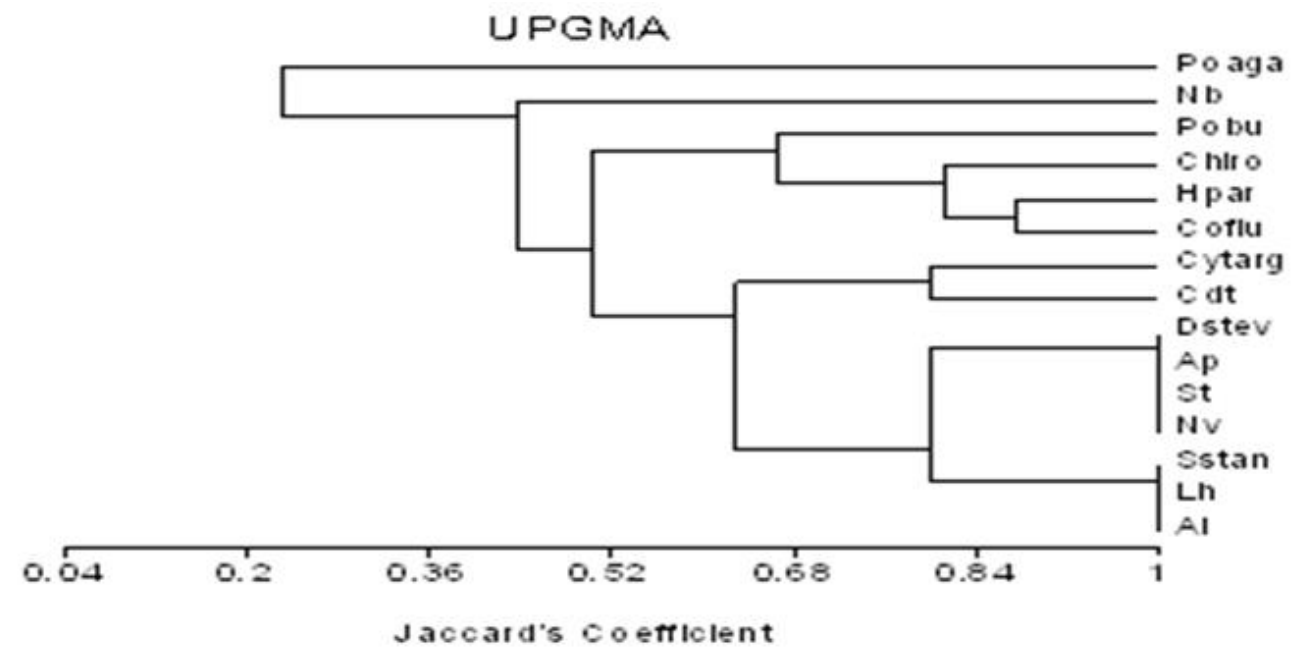

Fig. 4. Results of Cluster Analisys (UPGMA): Po aga, $P$. agapetus; $N$ b, $N$. bonettoi; Po bu, $P$. bushii; Chiro, Chironomidae; H par, H. parchapii; Co flu, C. fluminea; Cyt arg; C. argentinensis; C cdt, C. diastrophus; D stev, D. stevensoni; A p, A. piguetti; S t, S. trivandrana; N v, N. variabilis; S stan, S. stanfordi; L h, L. hoffmeisteri; A I, A. leydigi

\subsection{Community Parameters}

The community parameters (see Table 2) of diversity $\left(\mathrm{H}^{\prime}\right)$, equitability $(\mathrm{J})$, and species richness (S) were minimum and maximum, respectively, for $\mathrm{H}^{\prime}$ at 0.77 and 2.2 bits at sites 2 and 3 (summer 1996) and at 2.16 bits at site 8 (winter 1995); for $\mathrm{J}$ at 0.16 at site 4, (spring 1995) and 1.02 at site 2 (autumn 1995); and for (S) at 3 at site 3, (summer 1996) and 29 at site 7 (autumn 1995).

\subsection{Cluster Analysis}

The results of the unweighted pair group method with arithmetic mean (UPGMA) cluster analysis (as shown in Fig. 4) indicated the existence of two main groups of species. The first was composed of $P$. agapetus, $P$. buschii, N. bonetoi, the Chironomidae, $H$. parchapii, and $C$. fluminea at a $\mathrm{J}=0.60$ that combined with the second group containing Cytheridella argentinensis and Chaetogaster diastrophus along with $D$. 
stevensoni, A. pigueti, S. trivandrana, $N$. variabilis, S. stanfordi, $L$. hoffmeisteri, and $A$. leydigi at a maximum similarity index of $\mathrm{J}=0.80$.

\subsection{Canonical Correspondence Analysis Results}

In the canonical-correspondence analysis (see Fig. 5, Table 4), the arrows in the figure represent the environmental variables and point to the maximum variation in the indicated parameter, with the length of each arrow being proportional to the magnitude of that variable in the ordering diagram. According to this analysis, the environmental variables that underwent the greatest fluctuation during the study period were the dissolved-oxygen concentration, the $\mathrm{pH}$, the temperature, and the conductivity of the water. These results suggest that the distribution of the species is related to the physicochemical conditions of the water. Of the correlation between the species present and the environmental variables, $95.2 \%$ is distributed on Axis 1 of the ordering diagram (see Fig. 5). The dissolved-oxygen concentration, the $\mathrm{pH}$, and the temperature of the water correlated significantly with each other; but not with the electrical conductivity, which parameter became negatively related to these variables. The dissolved-oxygen concentration and the temperature were correlated with sites 4 and 2, respectively; whereas the $\mathrm{pH}$ became associated with sites 3 and 6 in the ordering diagram.

Generally, most of the analyzed species were distributed around the mean values of $\mathrm{pH}$, disolved oxygen and water temperature (see Fig. 5). According to the ordering diagram, the species most related to $\mathrm{pH}$, dissolved oxygen and water temperature were: $S$. stanfordi, $A$. leydigi, $L$. hoffmeisteri, $C$. diastrophus $D$. stevensoni, $N$. variabilis, $S$. trivandrana, $A$. pigueti, N. bonettoi and the family Chironomidae; while the ostracod $C$. argentinensis was located close to the centroid of the variables. The remaining species such as $C$. fluminea, $P$. buschii, H. parchapii and P.agapetus were related to electrical conductivity.

\subsection{Functional Feeding Groups}

As to the functional feeding groups (see Fig. 6), at all the sites and in all the seasons of the two years; the gathering collectors predominated, followed by the scrapers, filtering collectors, shredders, and predators.

\subsection{Macroinvertebrate Index of Pampean- Rivers (MIPR)}

Calculations of the MIPRS (see Fig. 7) at 6 of the 8 sampling sites-with sites 2 and 3 and sites 3 and 4 being combined because of their proximity and intermixing during high tides-gave maximum and minimum values of 19.2 (i. e., a very low degree of pollution to none at all) and 1.90 (i. e., a strong contamination). Site 1 exhibited a moderate level of contamination (at 3.00) in the winter 1996 and a considerately lower degree in the following autumn (at 8.25) along with somewhat higher levels (5.85 and 7.00 ) in the spring and early summer of that year. Site 3 manifested an extremely low pollution to none at all at 16.1 (summer 1995), a modest degree in autumn and winter at 8.80 and 9.30, respectively, and a considerably higher level at 4.40 and 5.20 in autumn and winter, respectively; whereas, in the spring and summer 1996, similarly high respective degrees of pollution were recorded at 4.40 and 5.20. At site 4 , the contamination was extremely low to none at all at from 13.8 to 19.2) in summer and autumn 1995, modest in the winter and summer 1996 (at 8.20 and 9.30 , respectively), and higher in the spring of that year (6.60). The contamination at site 6 was only very slight at 12.4 in the summer 1995 , somewhat greater at 6.10 in autumn of that year, once again quite low at 10.9 in the winter, high (2.10) in the spring, and finally much lower at 5.75 in the summer 1996 . Site 7 was usually substantially free of contamination at values between 8.25 and 11 , while site 8 exhibited comparable levels in the summer 1995 at 7.80 along with progressively lower degrees at 8.15 in the following autumn and 11.1 in the winter, though manifesting a high value of contamination $(2,4$ and 1,5$)$ in the spring of that year.

Table 4. Results from the canonical correspondence analysis (CCA)

\begin{tabular}{llll}
\hline & Axis 1 & Axis 2 & Axis 3 \\
\hline Eigenvalues & 0.112 & 0.038 & 0.14 \\
Percentage & 41.716 & 14.343 & 5.074 \\
Cum. Percentage & 41.716 & 56.059 & 61.133 \\
Cum.Constr.Percentage & 66.501 & 89.366 & 97.454 \\
Spec. env, Correlations & 0.952 & 0.824 & 0.595 \\
\hline
\end{tabular}




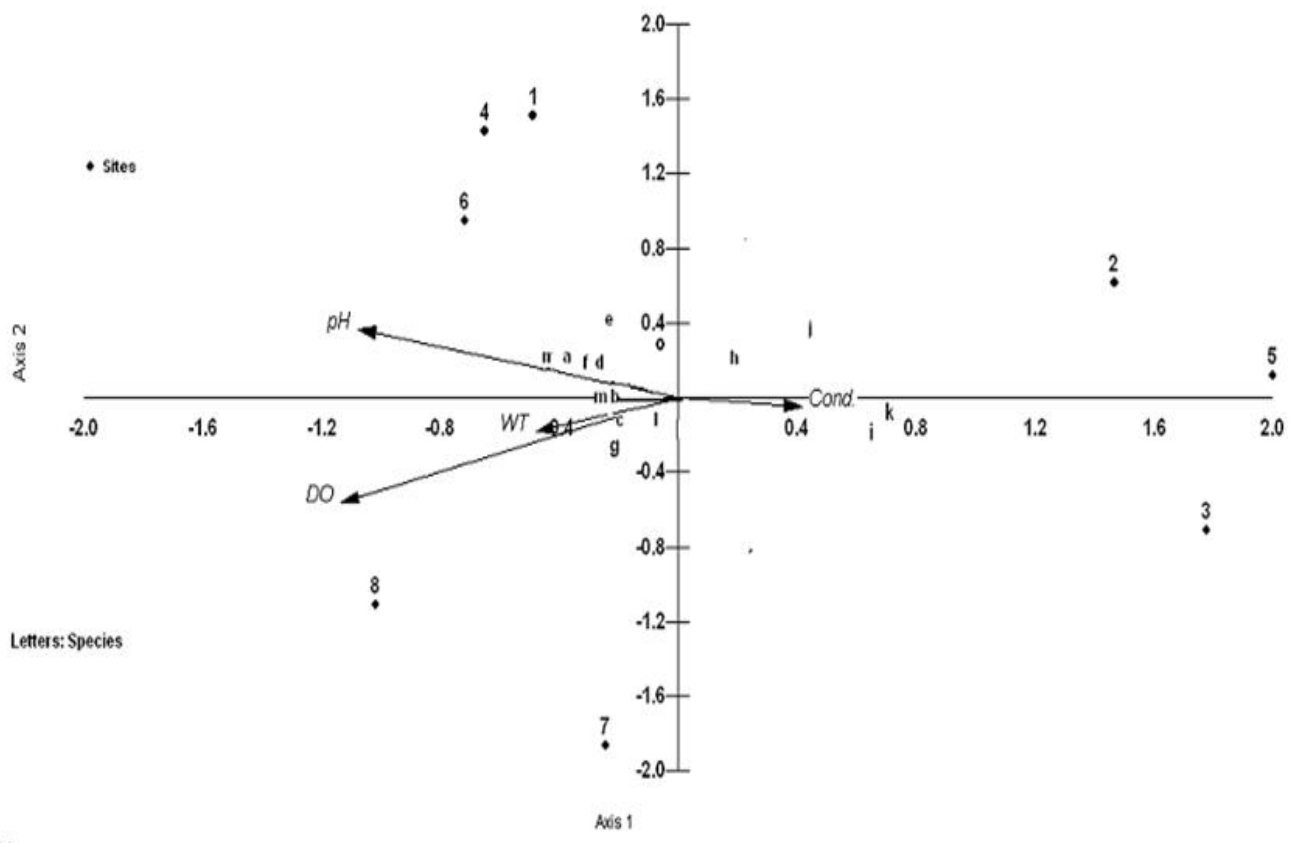

ector scalina: 1.29

Fig. 5. Canonical-correspondence-analysis diagram: 15 species, and 4 environmental variables. Abbreviations: a, A. leydigi; b, N. variabilis; c, S. trivandrana; d, C. diastrophus; e, N.bonettoi; f, L. hoffmeisteri; g, A. pigueti; h, C. fluminea; I, H. parchappii; j, P. buschii; k, P. agapetus; I, C. argentinensis; m, D. stevensoni; $\mathrm{n}$, S. stanfordi; o, Chironomidae. Sampling sites: 1-8

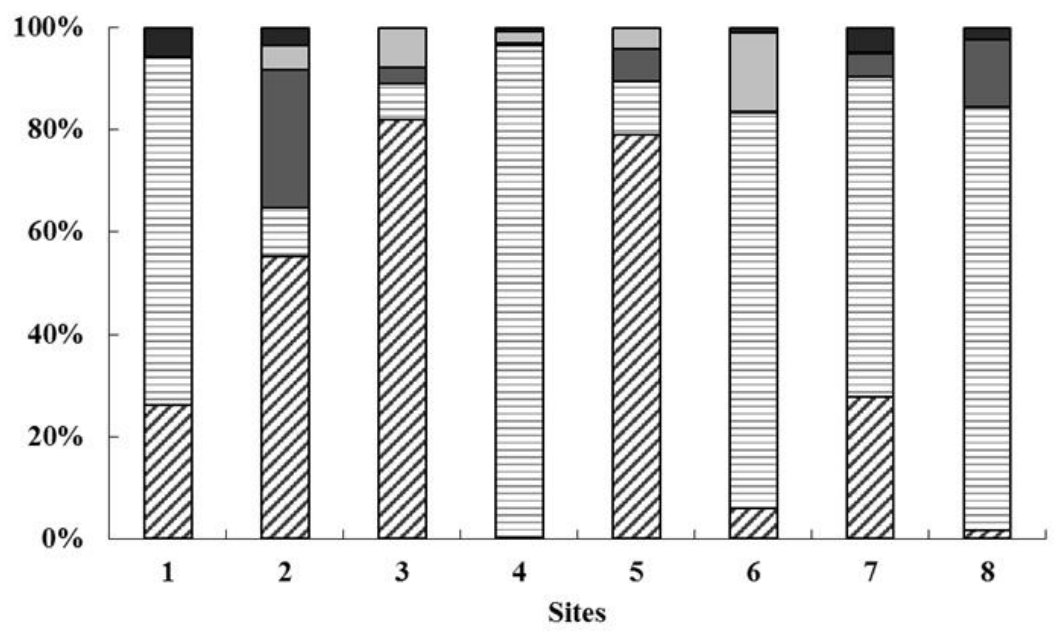

$\square$ Scrapers $\boxminus$ Gathering-collectors $\square$ Filtering-collectors $\square$ Shredders $\square$ Predators

Fig. 6. Percentage of functional feeding groups of the benthic community

\section{DISCUSSION}

In the Martín García Island Nature Reserve, the most abundant and representative macro- invertebrates in the littoral sites and seasons were the Nematoda, the oligochaete annelids, and the gastropods and bivalves among the Mollusca. The Nematoda evidenced a 
conspicuous representation at sites 1,4 , and 6 through 8 (see Table 2) and were found mainly in summer, autumn, and winter.

The Oligochaeta constitute an abundant group within the benthic organisms because the hydrosedimentologic dynamics of this and other great rivers create a wide heterogeneity of habitats as reflected in the spatial and temporal structure of the benthic communities $[77,75]$. This subclass has been recorded in almost all freshwater environments and is particularly abundant in the Paraná-Plata basin $[80,82,83$, $90,84,87,86]$.

In the littoral of this Nature Reserve, these annelids were represented by 21 species in addition to the families Aelosomatidae and Enchytareidae at sites 4 and 6 through 8 (Table 1 and Fig. 2); of the total taxa 19 species, Aelosomatidae and Enchytraeidae were present at Site 7 during the autumn and winter 1995 and summer 1996. This Site is characterized by a great development of grasslands, reeds, and a total of 16 species of hydrophytes [27]. At Site 8 -it contains a major development of reedbeds associated with mixed sediments of sand and silt-14 species of oligochaetes and the families Aelosomatidae and Enchytraeidae were recorded.

The oligochaete abundances were higher in autumn and winter 1995. Moreover, as has also been observed in areas of the Paraná River, $N$. bonettoi was linked to sandy sediments [91, 77, 85, 92]; and particularly at Site 4-that area characterized by medium and fine sands free of vegetation [34] - the species reached a relative abundance of $35 \%$ in the autumn as well as one of $98 \%$ in the spring of that year. In studies conducted by Ambrosio [66] covering a sector of the southern coastal strip along the Argentine side of the Río de la Plata estuary, all the species mentioned for the Martín García Island were registered; and their findings along the coast confirmed that the majority of oligochaete species is linked to areas with vegetation, such as was found at the present sites 7 and 8 .

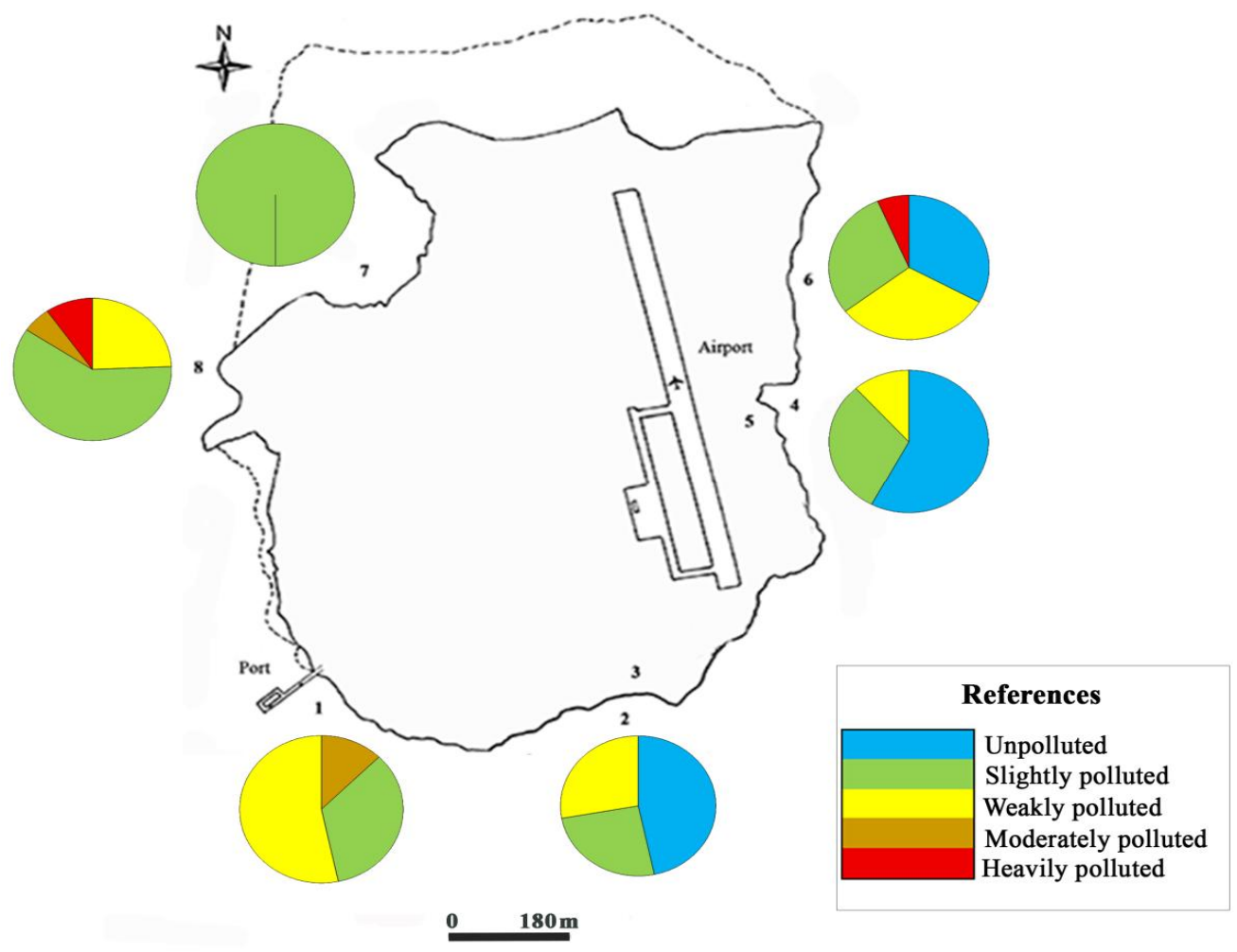

Fig. 7. Percent representation of each category established by the MAcroinvertebrate INDEX of Pampean Rivers (MIPR) for the sampling sites during the study period. Sites 2 and 3 and sites 3 and 4 are represented in single pie charts because of their proximity and intermixing during high tides 
The portion of the Río de la Plata estuary included in the Brazilian subregion [62] has been found to exhibit one of the highest speciesrichness values of Gastropoda [78,62]. The mollusks on the Martín García Island (Table 2, Fig. 2) - Represented by 21 species, 4 of the Bivalvia and 17 of the Gastropoda, that were found at all the sampling sites and in all the seasons-along with the oligochaetes, constituted the most abundant and diverse of the macroinvertebrate groups registered in the present survey. Ambrosio [66] had cited 10 species of gastropods linked to soft sediments and vegetation plus 4 species of bivalves along the coast. On the island, in the present work, species of the families Chilinidae and Lithoglyphidae were also registered adhering to the rocky substrate.

The Tardigrada were found at sites 1, 2, and 6 through 8; though always in low percentages except for Site 8 in the winter of 1995 (then at $17 \%)$. In addition to the Copepoda Cyclopoida, Calanoida, Harpacticoida, and Cladocera, eleven crustacean species were recorded at all sites and in all the seasons (see Table 2, Fig. 2); manifesting the highest abundances at sites 4, 5, and 6 through 8. Especially abundant at Site 6 was S. stanfordi (at $42 \%$ in the summer of 1995 and $30 \%$ in the autumn, though only $3 \%$ in the winter, which species was linked to the sediment and the presence of reeds, as mentioned by Rodrigues Capítulo et al. [66] for the Argentine coast.

The crustacean Claudicuma platensis (Cumacea) was recorded at only Sites 1, 2, and 4 and always at abundances less than $1 \%$. Five species of Ostracoda were registered at Sites 1, 2, and 4 through 8 in 1995: C. argentinensis (4\%) at Site 4 and $D$. stevensoni (13\%) and I. gibba $(1 \%)$ at Site 8 in summer along with $L$. paranensis $(14 \%)$ at Site 4 and $D$. stevensoni $(2 \%)$ at sites 7 and 8 in autumn. Members of the Ciprididae and Darwinulidae were recorded both in vegetated sites and at Site 4 having sandy sediments. Pseudosphaeroma platense exhibited a maximum relative abundance of $10 \%$ in spring 1995 at Site 1, there also in relation to the reedbed of that part of the island. The amphipod $H$. curvispina was recorded in both vegetated and non vegetated sites. Among the decapod crustaceans, $A$. uruguayana was collected with a crab net at sites 4 and 6 , while $A$. platensis was recorded at sites 2 and 4 along with members of the genus Temnocephala, commensals of that species [32].
Twelve families of insects belonging to 6 orders were identified (Table 2). The larvae of Chironomidae dipterons were recorded at all the sites except Site 3, with the highest relative abundance corresponding to the winter season at Sites 6 and 8, therein association with mixed sediments and vegetation of $S$. californicus. The coleopteroid family Psephenidae and the ephemeropteran family Baetidae manifested relatively higher distributions at those sampling sites. The families Coenagrionidae, Psephenidae, Baetidae, and Elmidae in combination were present at a relative abundance of $33 \%$ at Site 3 in summer 1995; the Pleidae and Ceratopogonidae together at one of $6 \%$ at Site 8 in that same summer; the Psephenidae at one of $26 \%$ at Site 3 and $48 \%$ at Site 5 , both in the winter; and the Pleidae at one of $8 \%$ at Site 7 in the spring. The remaining families were at relative abundances lower than those cited. All of these families of insects have been observed on the island, had been cited on the sector of the coast studied by Rodrigues Capítulo et al. [66], except for the Psephenidae, whose larvae inhabit littoral rocks.

With regard to species richness, 20 were registered at Site 1 in the winter and 22 at Site 2 in summer 1995. Although sites 3 through 5 contained lower numbers, sites 6 and 8 exhibited a greater richness-especially in autumn, winter, and spring. These sites offered a greater refuge for the development of benthic macroinvertebrates because of the presence of mixed sediments (silt plus sand) and an abundant development of hydrophytes. The diversity-as in other southern-coastal-strip sectors of the Río de la Plata-was higher wherever a greater differentiation of habitats occurred in association with marsh vegetation [47]. In contrast. the equitability varied in accordance with the climatic conditions and seasons.

Within the functional feeding groups (Fig. 6), the macroinvertebrate gathering collectors were represented in the benthos of the island's littoral by the oligochaete, nematode, crustacean and insects taxa. With the last two of these groups exemplified by the harpacticoid copepods, ostracods, $C$. platensis, the amphipod $H$. curvispina, and the tanaidacean $S$. stanfordi; among the insects, the Elmidae family of the order Coleoptera plus certain Chironomidae of the Diptera, the Hydroptilidae of the Trichoptera, and Baetidae of the Ephemeroptera were present. This feeding category characterized 
more than $80 \%$ of the macroinvertebrates at sites 1, 4, and 6 through 8 in almost all the seasons, an observation that had been made previously for different lotic environments of the Paraná-River basin [76, 78,79]. Ambrosio [66] reported for the coast of Punta Lara and La Balandra within the southern coastal strip, the dominance of such gathering collectors at higher than $80 \%$ in sediment-free vegetation. On the Martín García Island, this situation occurs in both the free sediments (e. g., at Site 4) and the vegetated ones (e. g., at sites 1 and 6 through 8).

The scrapers, represented principally by gastropod molluscs, were found in a large percentage at sites with rocky substrates such as Site 2 (68-97\%), Site $3(77-100 \%)$, and Site 5 (52-99\%). Sites 1 and 7 (those vegetated) had respective abundances of 55 and $82 \%$ during most of the seasons. Pavé \& Marchese [79] had reported very few macroinvertebrates belonging to this functional-feeding category in the environments of their study on the Paraná River. The investigations of [66], whose results coincided with those the previous authors cited for that sector of the Argentine coast of the Rio de la Plata, reported a scraper representation of $14 \%$.

The filtering collectors were represented by the bivalve molluscs such as $L$. fortunei, $P$. taraguyense, and $P$. sterkianum along with certain cyclopoid and cladoceran copepods. The highest representations of filtering collectors were recorded at Site 2 at $67 \%$ (e. g., L. fortunei, autumn 1995), Site 7 at 15\% (e. g., L. fortunei, $P$. sterkianum, and cyclopoids; summer 1996), Site 8 at 15\% (e. g., cladocerans, winter 1995), and Site 5 at $13 \%$ (e. g., cladocerans and $P$. sterkianum, spring 1995). The filtering collectors were not registered at Site 1 and in the remainder were present at only low percentages. These overall percentages were similar to those reported by Fujita and Takeda [88] and Rodrigues Capítulo et al. [66] for sites with the best water quality.

In the shredder category, the decapods Aegla platensis and Aegla uruguayana were recorded at sites 2 and 4 and at sites 4 and 6 , respectively, in the summer, autumn, and winter. The predators, in contrast were characterized by low percentages (at a maximum of $15 \%$ ) at sites $1,2,3$, and 6 through 8-represented by turbelaries, hirudineans, Hellobdella sp., oligochaetes such as Chaetogaster diastrophus and $C$. diaphanus, isopods such as $P$. platense, Ceratopogonidae dipterons, hemipterans, Pleidae, odonates, Coenagrionidae, and Libellulidae. Ambrosio [39] had reported similar values for those same coastal sampling sites.

The results of the UPGMA cluster analysis would appear to indicate that the coastal macroinvertebrate species of Martín García Island formed two main groups. Group 1containing $P$. agapetus, $P$. buschii, $H$. parchapii, $N$. bonetoi, $C$. fluminea, and the Chironomidaelinks those two species of Potamolithus to sites with rocky substrates (sites 2, 3, and 5) along with individual vegetated habitats-i. e., Site 7 for $P$. agapetus and Site 1 for $P$. buschii. Heleobia parchapii was registered in all but 4 sites and the Chironomidae in all sites except Site 3; while C. fluminea was common to all the sites as an infaunal bivalve, the distribution of which is closely related to abiotic parameters such as the type of substrate [64]. At a $\mathrm{J}=0.60$, all of these taxa are linked to the second group containing the ostracod $C$. argentinensis at sites 2 , 4, and 6 through 8 plus the annelid $C$. diastrophus at sites 4 and 6 through 8 along with the rest of the species cited in the Results section that combine as a cluster with an index of maximum similarity (i. e., $\mathrm{J}=0.80$ ).

With respect to the behaviour of the species in the face of environmental variables, of the 15 species considered in this analysis, the majority were ordered close to the average dissolvedoxygen concentration, $\mathrm{pH}$, and temperature; with $C$. argentinensis, the species located closest to the centroid of the diagram (as shown in Fig. 5), evidencing preferences for the mean values of the variables under consideration. Darwinula stevensoni had a correlation with the temperature, dissolved-oxygen concentration, and $\mathrm{pH}$ along with a negative association with the electrical conductivity. Sinelobus stanfordi (Tanaidacea) was sequestered like $D$. stevensoni. Of the Oligochaeta, A. leydigi exhibited a highly significant association with the dissolved-oxygen concentration; whereas, $S$. trivandrana also maintained a correlation with that parameter; C. diastrophus was associated with the $\mathrm{pH}$, and $N$. bonettoi with the conductivity; $L$. hoffmeisteri was correlated with only the dissolved-oxygen concentration; and $A$. pigueti was highly positively associated with the temperature, dissolved-oxygen concentration, and $\mathrm{pH}$-but negatively so with the conductivity. 
Among the mollusks, $H$. parchapii was highly positively correlated with the conductivity, but negatively associated with the temperature and the $\mathrm{pH}$ (see Fig. 5). Potamolithus buschii evidenced negative correlations with the temperature and the dissolved-oxygen concentration as did $P$. agapetus with the temperature and the $\mathrm{pH}$. The Chironomidae family maintained high positive associations with the temperature, dissolved-oxygen concentration, and $\mathrm{pH}$, but was negatively correlated with the Iconductivity.

The temperatures of the system were quite variable over time, is directly linked to the seasonal variation and the hydrodynamics of the ecosystem; whereas the average conductivity value in the littoral water of the island of ca. 135 $\mu \mathrm{S} . \mathrm{cm}^{-1}$ was considerably lower than the average figure of $259 \mu \mathrm{S} . \mathrm{cm}^{-1}$ reported for the water of the southern coastal strip. The guideline levels for quality as a function of the different uses of the island's resources, as indicated by the Use-IV range of parameters appropriate for the protection of the aquatic life indicated on the Water Quality meter of the [81], involve pHs of 6.5 to 8.5 and a dissolved-oxygen concentration of at least $5 \mathrm{mg} \cdot \mathrm{L}^{-1}$. The work reported here has confirmed that the average values of the environmental variables recorded on the island are still within that recommended range.

Living organisms are widely used as biotic indicators for the monitoring and evaluation of water quality, with the benthic macroinvertebrates being the most frequently recommended for aquatic ecosystems [82, 83, 84,79,85,86,87]. In Argentina, the benthic entomo-fauna have been used to evaluate the water quality of rivers and mountain streams by the application of the biotic indices Biological-Monitoring-Working-Party and Average-Store-per-Taxon $\quad[88,89,91,26]$. In studies monitoring the ecologic quality of the Matanza-Riachuelo basin (Buenos-Aires province) indices involving the meso- and macroinvertebrates [67], the diversity $\left(\mathrm{H}^{\prime}\right)$, and the deficit-of-species have been applied [93]. Based on such observations, the MIPR was formulated specifically for the rivers of the Argentine pampas $[67,68]$. In the present study, we observed a variation in the quality and quantity of the meso- and macroinvertebrates, as evidenced upon application of that index, that reflected the effect of contamination in the system.
Along the littoral of Martín García Island, the MIPR values (see Fig. 7) fluctuated both among the sampling sites and during the seasons of the year: The highest values were observed in the summer and autumn 1995 at sites 2, 4, and 6 (very weak contamination down to none at all), with the value of Site 2 being particularly relevant since that area corresponds to the intake of water that flows directly to the watertreatment plant of the island supplying the resident population of the island (in years of the study, about 150 inhabitants) along with tourist contingencies that visit the island.

In general, we can state that the MIPR values ranged from only weak to weak-to-very-weak to zero pollution. Two exceptions, however, were registered at values reflecting strong contamination, both in the spring and at sites 6 (2.4) and 8 (1.9). At Site 6, this discrepancy could have resulted from the use of only 4 taxa with values of low ecologic sensitivity and a predominance of nematodes (at $77 \%$ ). The explanation for Site 8 is similar to that of Site 6, but with the further aggravating circumstance of the site's proximity to the island's garbage dump, whose refuse could have entered the water during high tides. The results of [66] are quite similar to those calculated for the island although with values indicating higher pollution levels.

The work reported here constitutes the first investigation considering the use of macrobenthic invertebrates as indicators of water quality in the Martín García Island Nature Reserve. These findings can serve as the basis for additional investigations that, after a lapse of 23 years, are being carried out on the current state of the island's community and the quality of the internal and coastal water. We trust that these observations and conclusions will be of assistance in the development of the appropriate environmental-management policies by the relevant enforcement authorities.

\section{CONCLUSION}

A total of 71 taxa were collected in the Martín García island Nature Reserve during the study period. The most abundant and representative macroinvertebrates in the littoral sites and seasons were the nematoda, the oligochaete annelids, and the gastropods and bivalves among the mollusca.

The density of the benthic macroinvertebrates ranged from 15 to 58,800 ind. $\mathrm{m}^{-2}$. The ANOVA 
revealed significant differences between the values for the average annual population density of macroinvertebrates among the five sites included in the analysis ( $F: 3.059 ; p<0.05)$. The highest average population density was recorded at Site $8\left(38,700 \pm 19,000\right.$ ind $\left.\mathrm{m}^{-2}\right)$.

The community parameters of diversity $\left(\mathrm{H}^{\prime}\right)$, equitability $(\mathrm{J})$, and species richness $(\mathrm{S})$ were minimum and maximum, respectively, for $\mathrm{H}^{\prime}$ at 0.77 and 2.2 bits at sites 2 and 3 (summer 1996) and at 2.16 bits at site 8 (winter 1995); for $\mathrm{J}$ at 0.16 at site 4 , (spring 1995) and 1.02 at site 2 (autumn 1995); and for (S) at 3 at site 3, (summer 1996) and 29 at site 7 (autumn 1995).

The results of the UPGMA cluster analysis indicated the existence of two main groups of species.

According to CCA, the environmental variables that underwent the greatest fluctuation were the dissolved-oxygen concentration, the $\mathrm{pH}$, the temperature, and the conductivity of the water. These results suggest that the distribution of the species is related to the physicochemical conditions of the water. Of the correlation between the species present and the environmental variables, $95.2 \%$ is distributed on Axis 1 of the ordering diagram.

As to the functional feeding groups, at all the sites and in all the seasons of the two years; the gathering collectors predominated, followed by the scrapers, filtering collectors, shredders, and predators.

Along the littoral of the island, the MIPR values fluctuated both among the sampling sites and during the seasons of the year: the highest values were observed in the summer and autumn 1995 at sites 2, 4, and 6 (very weak contamination down to none at all), with the value of site 2 being particularly relevant since that area corresponds to the intake of water that flows directly to the water-treatment plant of the island supplying the resident population of the island. In general, we can state that the MIPR values ranged from only weak to weak-to-veryweak to zero pollution.

The work reported here constitutes the first investigation considering the use of macrobenthic invertebrates as indicators of water quality in the Martín García Island Nature Reserve.

\section{ETHICAL APPROVAL}

As per international standard written ethical permission has been collected and preserved by the authors.

\section{ACKNOWLEDGEMENTS}

Financial support for this work was provided by an institutional grant from the Comisión de Investigaciones Científicas de la Provincia de Buenos Aires $(\mathrm{ClC})$ - the first and second authors are $\mathrm{CIC}$ researches-, and the Facultad de Ciencias Naturalesy Museo, Universidad Nacional de La Plata (Proyect 11/N470).

The authors wish to thank to Dr. Donald Haggerty, a career investigator and native English speaker, edited the final version of the manuscript.

\section{COMPETING INTERESTS}

Authors have declared that no competing interests exist.

\section{REFERENCES}

1. Segnini S. The use of benthic macroinvertebrates as indicators of the ecological condition of bodies of running water. Ecotropicos. Venezuelan Ecology Society. Spanish. 2003;16(2):45-63.

2. Hauer FR, Resh VH. Benthic Macroinvertebrates. In Hauer FR, Lamberti GA (ed): Methods in Stream Ecology. Academy Press, New York. 1996;339-369.

3. Reece P, Richardson JS. Biomonitoring with the reference condition approach for the detection of aquatic ecosystem at risk. Pp. 549- 552 in L.M. Dearling (ed): Proceedings of a conference on the biology and management of species and habitats at risk, Kamloops, B.B. 2000;2.

4. Cairns JJR, Pratt JR. A history of biological monitoring using benthic macroinvertebrates. In Rosemberg DM, Resh VH (eds.): Freshwater Biomonitoring and Benthic Macroinvertebrates. Chapman y Hall, New York. 1993;10-27.

5. Resh VH, Jackson JK. Rapid assessment approaches to biomonitoring using benthic macroinvertebrates. Rosemberg DM, Resh VH (eds.): Freshwater Biomonitoring and 
Benthic Macroinvertebrates. Chapman y Hall, New York. N.Y. 1993;195-223.

6. Rosemberg DM, Resh VH. Use of aquatic insects in biomonitoring; 87-97.

7. Merritt KW. Cummins (eds.) An Introduction to the aquatic insects of North America, $3^{\mathrm{a}}$ ed. Kendall/Hunt, Dubuque, I.A; 1996.

8. Barbour MT, Gerritsen J, Snyder BD, Stribling JB. Rapid bioassessment protocols for use in streams and wadeable rivers: Periphyton, benthic macroinvertebrates and fish. Second edition. EPA 841B-99-002. U.S. Environmental Protection Agency; Office of Water; Washington, D.C; 1999.

9. Karr JR, Chu EW. Restoring life in running waters: Better biological monitoring. Island Press Washington, D.C; 1999.

10. Roldán GA. Bioindication of water quality in Colombia: Use of the BMWP / Col method. University of Antioquia. Colombia; 2003. Spanish.

11. Fernández $H$, Romero $F$, Grosso $L$, de Grosso M, Peralta M, Rueda M. The diversity of zoobenthos in mountain rivers of the NOA, I: The Zerda River, province of Tucumán, Argentine Republic. Acta Zool. Lill. 1995;43 (1):215-219. Spanish.

12. Domínguez $\mathrm{E}$, Fernández $\mathrm{H}$. Quality of the rivers of the Salí basin (Tucumán, Argentina) measured by a biotic index. Series Nature conservation. Miguel Lillo Foundation No 12. Tucumán. 1998;39. Spanish.

13. Fernández $H$, Domínguez $E$ (Eds.). Guide for the determination of South American bentonic arthropods. Research Series of the UNT. Subserie Exact and Natural Sciences. Science and Technology Secretary. Editorial of the University of Tucumán. 2001;283. Spanish.

14. Fernández $H$, Domínguez $E$, Romero $F$, Cuezzo G. Water quality and bioindication in the mountain rivers of the Argentine Northwest. Conservation of Nature Series No 16. Miguel Lillo Foundation. Tucumán, Argentina. 2006;36. Spanish.

15. von Ellenrieder N. Composition and structure of aquatic insects assemblages of yungas mountain cloud forest stream in NW Argentina. Rev. Soc. Entomol. Argent. 2007;66(3-4):57-76.

16. Gualdoni C, Corigliano M. The adjustment of a biotic index for regional use. Rev. UNRC. 1991;11(1):43-49. Spanish.
17. Vallania E, Garelis P, Tripole E, Gil M. A biotic index for the san luis mountains. Rev. UNRC. 1996;16(2):129-136. Spanish.

18. Marchese M, de Drago IE. Use of benthic macroinvertebrates as organic pollution indicators in lotic environments of the Parana River dranaige basin. Polskie Arch. 19. Hidrobiol. 1999;46(3):233255.

19. Rodríguez Capítulo A, César I, Tassara M, Paggi A, Lemnicov $M$. Distribution of the macrobenthic fauna of the south coastal fringe of the Rio de La Plata (Argentine): impact of urban contamination. Inter. Assoc. Theor. Applied Limn. 1998;26(3): 1260-1265.

20. Miserendino ML. Composition and distribution of the macrozoobenthos of an Andean-Patagonian lotic system. Ecol. Austral. 1995;5:133-142. Spanish.

21. Miserendino ML. Uses of the land and communities of aquatic insects in Patagonia rivers, the 'systematic' problems that ecologists found. In: Abstracts Book of the VI Argentine Congress of Entomology. Argentine Society of Entomology. Tucumán. 2005;55. Spanish.

22. Miserendino ML, Hollmann E, Masi C. Benthos distribution and environmental relationships in a Chubut regulated river. In: Abstracts Book of III Argentine Limnology Congress. Chascomús (Bs. As.). 2005;66.

23. Vides Almonacid R, González J, Grosso L, Labilla E. Bioindicators. In: Biodiversity of Agua Rica Catamarca-Argentina. Lavilla, E. y J. Gonzáles (Eds.) BHP Copper and Miguel Lillo Fundation. U.N.T. 1999;253261.

24. Fernández $\mathrm{H}$, Romero $\mathrm{F}$, Vece $\mathrm{M}$, Manzo $V$, Nieto $C$, Orce M. Evaluation of three biotic indices in a subtropical mountain river (Tucumán-Argentina). Limnetica Rev. Asoc. Española Limnol. 2002;21(1-2):1-13. Spanish.

25. Fernández $\mathrm{H}$, Domínguez $\mathrm{E}$, Romero $\mathrm{F}$, Cuezzo G. Water quality and bioindication in the mountain rivers of the Argentine Northwest. Conservation of Nature Series No 16. Miguel Lillo Foundation. Tucumán, Argentina. 2006;36.

26. Fernández $\mathrm{H}$, Molineri $\mathrm{C}$. Toward a sustainable experience in an intermountain valley in northwestern Argentina. Ambio. 2006;35(6):262-266.

27. Colla MF, César II, Salas LB. Benthic insects of the El Tala River (Catamarca, 
Argentina): Longitudinal variation of their structure and the use of insects to assess water quality. Braz. J. Biol. 2013;73(2): 357-366.

28. Lahitte HB, Hurrell JA. The trees of the martín garcía island: Trees and arborescent shrubs (native and naturalized) of the Martín García Island Natural and Cultural Reserve. La Plata: CIC. 1994;200. Spanish.

29. Juárez MC. Reserva and categorization of the categorization of the Reserva Natural Isla Martín García, Río de Plata Superior. Neotrópica. 1995;41(105106):83-88.

30. Lahitte HB, Hurrell JA Canda G, Trucco Alemán C. Tupinambis teguixin populations (Sauria-Teidae) of Martín García Island (Buenos Aires, Argentina). I Etnobiología y Encuadre MetodológicoCognitivo Pinaco. 1995;2:45-62.

31. Lahitte HB, Hurrell JJ. Birds Catalog of the Martín García Island (Buenos Aires, Argentina). Ed. La Plata, CIC. (Serie informe, no. 53). 1998;53-69. Spanish.

32. Rumi A, Martin SM, Tassara MP, Darrigran GA. Freshwater mollusks of the Martín García Island Natural and Historical Reserve Río de la Plata, Argentina Com. Soc. Malacol.Uruguay 1996;8(70-71):7-12.

33. Damborenea MC, César II, Armendáriz LC. Species of Temnocephala (Platyhelminthes: Temnocephalidae) of Martín García Island, Buenos Aires, Argentina Neotropica 1997;43(109-110): 123-124. Spanish.

34. Fernández LOA, López Ruf M. Aquatic coleoptera and heteroptera of the martín garcía island (Buenos aires province). Physis Secc B. 1999;57(132-133):1-4.

35. Armendáriz LC, César II, Damborenea MC. Oligochaetes in lentic environments in the Natural and Historical Reserve of Martín García Island, Rio de la Plata Superior, Argentina. Asoc. Cs. Nat. Lit. 2000;31(1-2):73-79. Spanish

36. Armendáriz LC, César II. The distribution and ecology of litoral oligochaeta and aphanoneura (Annelida) of the natural and historical reserve of isla martín garcía, Río de la Plata River, Argentina. Hydrobiolgia. 2001;463:207-216.

37. César II, Armendáriz LC, Damborenea C. Ostracoda (Crustacea) from Martín García Island, Río de la Plata, Argentina. Nat. Neotropic. 2001;32(2):147-151.

38. Rumi A, Gutiérrez Gregoric D, Roche A, Tassara MP. Population structure in
Drepanotrema cimex and D. kermatoides (Gastropoda, Planorbidae) in natural conditions. Malacol Michigan, USA. 2004; 45 (2):453-458.

39. Martín SM, Negrete LH. First register of Heleobia guaranitica (Doering, 1884) (Gastropoda: Cochliopidae) on Natural Reserve of Multiple Use Isla Martín García. Com. Soc. Malacol Uruguay. 2006;9(89): 71-73. Spanish.

40. César II, Liberto R. Ostracoda, possible indicator of environmental environmental degradation of the Martín García Island Multiple Use Reserve? Rev. Ciencia. 2008; 3 (5):99-108. Spanish.

41. César II, Martín SM, Gullo BS, Liberto R. Biodiversity and ecology of hirudinea (Annelida) from the natural reserve of isla martín garcia, Río de la Plata, Argentina. Braz. J. Biol. 2009;69(4):1107-1113. [PMID: 19967181] Available:http://dx.doi.org/10.1590/S151969842009000500014

42. Martín SM. Individual growth Heleobia piscium in natural population (Gastropoda: Cochliopidae) from the multiple use natural reserve isla martín garcía, Buenos Aires, Argentina. Braz. J. Biol. 2008;68(3):617621.

Available:http://dx.doi.org/10.1590/S151969842008000300020

[PMID: 18833484]

43. Martín SM, César II, Liberto R. Distribution of Deroceras reticulatum (Müller) (Pulmonata Stylommatophora) in Argentina with the first record of the Reserva de Usos, Isla Martin Garcia, Río de la Plata superior; 1774.

44. Díaz AC, Martin SM Population structure of Uncancylus concentricus (d'Orbigny, 1835) (Ancylidae, Pulmonata, Basommatophora) in the multiple use reserve martín garcía island, Upper Río de la Plata, Argentina. Braz. J. Biol. 2012;72(1):1-6.

45. Martín SM, Díaz AC. Histology and gametogenesis in Heleobia piscium (Cochliopidae) from the Multiple Use Reserve" Isla Martín García," Buenos Aires, Argentina. PEERJ. 2016;2548:1-11. DOI: 10.7717 / peerj

46. Liberto R, Mesquita-Joanes F, César II. Dynamics of pleustonic ostracod populations in small ponds on the island of Martín García (Río de la Plata, Argentina). Hidrobiología. 2012;688:47-61.

47. Liberto R, César II, Mesquita-Joanes F. Postembryonic growth in two species of 
freshwater ostracoda (Crustacea) shows a size-age sigmoid model fit and temperature on development time, but no clear-temperature-rule rule (TSR) pattern. Limnology. 2014;15:1-13.

48. César II, Martín SM, Rumi A, Tassara MP. Mollusks (Gastropoda and Bivalvia) of the multi-use reserve martín garcía island, río de la plata river: Biodiversity and ecology. Braz. J. Biol. 2012;72(1):1-10.

Available:http://dx.doi.org/10.1590/S151969842012000100014

[PMID: 22437379]

49. César II. Annelida (Oligochaeta and Aphanoneura) from the natural reserve of isla martín garcía (Upper Río de la Plata estuary, Argentina): Biodiversity and response to environmental variables. Braz. J. Biol. 2014;74(1):128-136.

Available:http://dx.doi.org/10.1590/15196984.21412

50. Urien CM. Río de la plata estuary. Environments Mem Geol Soc. America. 1972;33:213-234.

51. Dalla Salda L. the basament of martin garcía island río de la plata rev. Asoc. Geol Arg. 1981;26(1):29-43. Spanish

52. Ravizza GB. Principal geological aspects of Cuaternary on the Martín García Island, upper Río de la Plata. Rev. Asoc. Geol Arg. Bs. As. 1984;39(1-2):125-130.

53. González MA, Ravizza G. Estuary sediments of the late pleistocene and holocene in martín garcía island, Río de la Plata. Rev. Asoc.Geol. Arg. 1987;42(3-4): 231-243. Spanish.

54. Topics in Medical Malacology Barbosa FS (organizer). Ed. Fiocruz. 1995;268. Portugués.

55. Anderson RO. A modified flotation technique for sorting down fauna samples $L \& O$. 1959;4:223-225.

56. Brinkhurst RO, Marchese M. Guide for the identification of continental aquatic oligochaetes of South and Central America. Asoc. Cs. Nat. Lit. Col. Climax Seg. Ed. Santo Tomé (S.F.) Argentina. 1992;6:207. Spanish

57. Christoffersen ML. A catalog of aquatic microdrile oligochaetes (Annelida: Clitellata) from South America. Acta Hydrobiol Sin. 2007;31:59-86.

58. Christoffersen ML. Catalog of the lumbricidae (Annelida, Clitellata, Lumbricoidea) from South America, with remarks on the systematics of the Lumbricina. Zoosystema. 2011;33(2):141-173.
59. Lopretto E, Tell G (Directores). Continental water ecosystems: Methodologies for their study. Tomo II. Ediciones Sur (La Plata). 1995;709-731.

[ISBN 950-9715-31-X]

60. Margaleff R. Limnology indicator organisms. Biology of inland waters Forestry Institute of Investigations and Experiences, Minister of Agriculture Madrid; 1955. Spanish.

61. Begon M, Harper JL, Townsend CR. Ecology: Individuals, populations and communities Barcelona: Ed. Omega SA; 1988. Spanish.

62. Merritt RW, Cummins KW, Berg MB (editors). An introduction to the aquatic insects of North America 4a ed Kendall / Hunt Publishing Company; 2008.

63. Bonetto AA, Wais IR. Southern south american streams and rivers cap 9. In: Cushing CE, Cummins KW, Minshall GW (eds.), Elsevier Sciencie B. V. Ecosystems of the World 22. River and streams Ecosystems: Amsterdam; 1995.

64. Heino J, Soininen J, Lappalainen J, Virtanen $R$. The relationship between species richness and taxonomic distinctness in freshwater organisms. Limnol. \& Oceanog. 2005;50(3):978986.

65. Cummins KW, Merritt RW, Andrade PCN. The use of invertebrate functional groups to characterize ecosystem attributes in selected streams and rivers in south Brazil. Stud Neotrop. Fauna Environ. 2005;40(1): 69-89.

66. Tangorra M. Colonización y descomposición especies vegetation en ligne en ligne de las ciento Trabajo de Tesis Doctoral Facultad de Ciencias Naturales y Museo Universidad Nacional de La Plata. 2004; 118.

Available:http://hdl.handle.net/10915/4488 Spanish

67. Ambrosio ES. Habitats and food functional groups of the benthic macroinvertebrates in the Buenos Aires coast of the Río de la Plata; Relationship with pollution. Tesis de doctorado; 2014.

Available:http://sedici.unlp.edu.ar/ .

68. Rodrigues Capítulo A, Paggi AC, César II, Tassara M. Monitoring the ecological quality of the matanza riachuelo basin. In: Resúmenes II Congr. Argent de Limnología, Buenos Aires. 1997;138.

69. Rodrigues Capítulo A. The macroinvertebrates as quality indicators of lotic 
environments in the Pampean area. Rev. Soc. Entomol Arg. 1999;58:208-217.

70. Rodrigues Capítulo A, Tangorra M, OCÓN C. Use of benthic macroinvertebrates to assess the biological status of pampean streams in argentina Aq. Ecolog. Kluwer Academic Publishers Printed in the Netherlands. 2001;35: 109-119.

71. Ter Braak CJF. Canonical Correspondence Analysis: A new eigenvector technique for multivariate direct gradient analysis. Ecology. 1986;67(5):1167-1179.

72. Külköylüoğlu $\mathrm{O}$. Ecology of freshwater Ostracoda (Crustacea) to Lakes and Reservoirs in Bolu, Turkey J. Fresh. Ecol. 2003;18(3):343-347.

73. Külköylüoğlu $\mathrm{O}$, Dügel $\mathrm{M}$. Ecology and spatiotemporal patterns of Ostracoda (Crustacea) to Lake Gölcük (Bolu, Turkey). Arch. Für Hydrobiol. 2004;160(1):67-83.

74. Külköylüoğlu O. Ecology and phenology of freshwater ostracodes in Lake Gölköy (Bolu, Turkey). Aq. Ecol. 2005;39(3):295304.

75. Kovack W. Multi-Variate statistics package. Version 3.1. Pentraeth; 1998.

76. Ezcurra de Drago I, Marchese M, Wantzen KM. Benthos of a large Neotropical river: Spatial patterns in Benthic invertebrate community structure along the lower Paraguay floodplain system. Arch. Für Hydrobiol. 2004;160:347-374.

77. Crisci JV, López Armengol MF. Introducción a la teoría and pracctica de la taxonomía numerica. Washington: OEA. (serie de biología, no. 26). 1983;132.

78. Marchese M, Ezcurra de Drago I. Benthos of the lotic environments in the Paraná River system: Transverse zonation. Hydrobiologia. 1992;237:1-13. Rumi A, Gutiérrez Gregoric DE, Núñez V, César II, Roche MA, Tassara MP, Martín SM, López Armengol MF. Freshwater gastropod from Argentina: Species richness, distribution patterns, and an evaluation of endangered species. Malacologia. 2006;49(1):189208.

79. Higuty J, TAKEDA AM. Spatial and temporal variation in densities of chironomid larvae (Diptera) in two lagoons and two tributaries of the Upper Paraná River Floodplain. Braz. J. Biol. 2002; 62(4B):807-818.

Available:http://dx.doi.org/10.1590/S151969842002000500010

80. Takeda AM, Shimizu GY, Higuti J. Spatiotemporal variations of the zoobentic community. In Vazzoler AEAM, Agostinho AA, Hahn NS. (Eds.). Planície de inundação do Alto Rio Paraná. Maringá: EDUEM. 1997;157-177.

81. Pavé $P$, Marchese $M$. Benthic invertebrates as indicator of urban rivers (Paraná-Entre Ríos). Ecol. Austral. 2005; 15:185-197.

82. Takeda AM. Oligochaeta community of alluvial upper Paraná River, Brazil: Spatial and temporal distribution (1987-1988). Hydrobiologia. 1999;412:35-42.

83. Stevaux JC, Takeda AM. Geomorphological processes related to density and variety of zoobenthic community of the upper Paraná river (Brazil). Zeit. Geomorphol. 2002;129:109-129.

84. Marchese M. New contributions to the knowledge of the oligochaetes of the paraná medio river and some tributaries. Studies on Neotropical Fauna and Environment. 1986;21:231-249. Spanish.

85. Marchese M. The ecology of some benthic Oligochaeta from the Paraná River. Hydrobiologia. 1987;155:209-214.

86. Behrend RDL, Fernandes SEP, Fujita DS, Takeda AM. Eight years of monitoring aquatic oligochaeta from the bahía and Ivinhema Rivers. Braz. J. Biol. 2009; 69(Supplement 2): 559-571.

Availabble:http://dx.doi.org/10.1590/S1519 $-69842009000300011$

87. Da Silva Gama AM. Distribution and richness of the benthic molluscs of the Araçá-RS lagoon Dissertação de Mestrado, Porto Alegre-RS-Brasil. 2004;1-35.

88. Water quality of the of the South Coastal Strip of the Río de la Plata (San Fernando -Magdalena. 1A Ed.) Consejo Permanente for Monitore de la Fronzada Costera Sur del Río de Plata; 1997 Spanish

89. Rosenberg DM, Resh VH. Use of insects in biomonitoring Pages 8797 in: Merritt RW, Cummins KW. eds. An Introduction to the Aquatic Insects of North America $3^{\text {rd }}$ ed. Kendall / Hunt, Dubuque, lowa; 1996.

90. Takeda AM, Fujita DS. Benthic invertebrates. In: Thomaz SM, Agostinho AA, Hahn NS. eds. The Upper Paraná River and its Floodplain. Leiden, Backhuys Publishers. 2004;192-207.

91. Righi G, Varela ME. Narapa bonettoi, gen. nov. sp. nov. (Oligochaeta, Narapidae, fam. nov.) freshwater from Argentina. Natura Neotropicalis. 1983; 1(14):7-15. 
92. Paggi AC. Chironomidae. In: Morrone JJ, Coscarón S. (eds.). Biodiversity of argentine arthropods: A biotaxonomic perspective, Editions South, La Plata. 1998;327-337. Spanish.
93. Figueroa $R$, Valdovinos C, Araya E, Parra O. Benthic macroinvertebrates as water quality of south of Chile rivers. Rev. Chi Hist. Nat. 2003;76:275285.

(c) 2019 César et al.; This is an Open Access article distributed under the terms of the Creative Commons Attribution License (http://creativecommons.org/licenses/by/4.0), which permits unrestricted use, distribution, and reproduction in any medium, provided the original work is properly cited.

Peer-review history:

The peer review history for this paper can be accessed here: http://www.sdiarticle3.com/review-history/49550 